
ЗАГРОЗИ ТРАНСПОРТНІЙ БЕЗПЕЦІ УКРАЇНИ ЗА УМОВ ГЛОБАЛІЗАЦІї:
ДЕРЖАВНО-УПРАВЛІНСЬКИЙ АСПЕКТ

\title{
THREATS TO THE TRANSPORT SECURITY OF UKRAINE IN THE CONDITIONS OF GLOBALIZATION: PUBLIC ADMINISTRATION ASPECT
}

Сучасний етап розвитку українського
суспільства характеризується зростаючою
роллю транспортної сфрери. Вона є його
системоутворюючим чинником та активно
впливає на стан економічної, політичної,
оборонної та інших складових частин без-
пеки України. Від забезпечення транспорт-
ної безпеки залежить національна безпека
України, яка зростає в ході технічного про-
гресу.

Питанням забезпечення транспортної безпеки в Україні поки що приділяється недостатньо уваги. Зокрема, поки що не прийняті основні нормативні документи в цій сорері: стратегія та концепція транспортної безпеки, закон про транспортну безпеку, а заходи, що вживаються, зазвичай відрізняються невисокою ефективністю. Водночас забезпечення належного рівня транспортної безпеки є одним з основних завдань сучасноі держави. Це підтверджується увагою, яка приділяється сьогодні у розвинених країнах світу питанням безпеки, зокрема транспортної, а також зумовлено величезним значенням транспорту для будь-якої сучасної країни.

Визначено фрактори забезпечення транспортної безпеки, основні загрози на транспорті. Коротко розглянуто склад транспортного комплексу держави й орієнтовний перелік об'єктів транспорту, що підлягають охороні.

Наведено основні причини низького рівня транспортної безпеки в Україні та спектр загроз транспортній безпеці.

Транспортна безпека насамперед проявляється у задоволенні транспортних потреб держави, ї економіки, оборонного комплексу для стійкого та гармонійного розвитку суспільства, захисту його національних інтересів.

Нинішня система державного управління безпекою на транспорті потребує вдосконалення. Відсутній єдиний орган управління транспортною безпекою держави, саме тому відсутня єдина загальна координація дій суб'єктів забезпечення транспортної безпеки України. Необхідне вдосконалення взаємодії всіх органів виконавчої влади та відповідних силових структур, які відповідають і беруть участь у забезпеченні транспортної безпеки. Відповідно до завдань $і$ функціональних обов'язків правоохоронних органів, спецслужб і контролюючих служб повинні бути більш чітко визначені на законодавчому рівні їх роль, місце та відповідальність як учасників прочесу забезпечення транспортної безпеки.
Ключові слова: транспорт, європейська інтеграція, захищеність, загрози, транспортна безпека, національна безпека.

The current stage of development of Ukrainian society is characterized by the growing role of the transport sector. It is its system-forming factor and actively influences the state of economic, political, defense and other components of Ukraine's security. The national security of Ukraine, which is growing in the course of technical progress, significantly depends on ensuring transport safety.

Insufficient attention is paid to the issue of ensuring transport safety in Ukraine so far. In particular, the main normative documents in this area have not been adopted yet: the strategy and concept of transport safety, the law on transport safety. And the measures taken, as a rule, differ in low efficiency. However, ensuring an adequate level of transport safety is one of the main tasks of the modern state. This is confirmed by the attention paid today in the developed world to security issues, including transport, as well as due to the great importance of transport for any modern country.

Factors for ensuring transport safety, the main threats to transport have been identified. The composition of the transport complex of the state and the approximate list of transport objects which are subject to protection are briefly considered.

The main reasons for the low level of transport safety in Ukraine and the range of threats to transport safety are presented.

Transport security is primarily manifested in meeting the transport needs of the state, its economy, defense complex for sustainable and harmonious development of society, protection of its national interests.

The current system of public transport safety management needs to be improved. There is no single body for managing the transport safety of the state, which is why there is no single general coordination of actions of the subjects of transport safety of Ukraine. It is necessary to improve the interaction of all executive bodies and relevan law enforcement agencies that are responsible for and involved in ensuring transport safety. In accordance with the tasks and functional responsibilities, law enforcement agencies, special services and control services should be more clearly defined at the legislative level their role, place and responsibility as participants in the process of ensuring transport safety.

Key words: transport, European integration, security, threats, transport security, national security.
Постановка проблеми у загальному вигляді. За умов глобалізації процесів світового розвитку, міжнародних політичних та економічних відносин, які формують нові загрози та ризики для розвитку особистості, суспільства та держави, Україна як гарант добробуту національного розвитку нині переходить до нової державної політики у сфері національної транспортної безпеки. Реалізація визначеної державної системи правових, економічних, організаційних та інших заходів у сфері транспортного комплексу є однією з обов'язкових умов забезпечення національних інтересів і національної безпеки. 
Черговий етап науково-технічного прогресу, яким переймається світ, технологічна революція, інновації показують усі сторони суспільного розвитку. Змінюється спосіб мислення мільйонів людей. Процеси глобалізації торкаються дедалі більшої кількості сфер людської діяльності. Все це значним чином впливає на зміст державної політики у сфері забезпечення транспортної безпеки, програми їі реалізації, на формування та приведення в дію механізмів її виконання.

Сучасний етап розвитку українського суспільства характеризується зростанням ролі транспортної сфери. Вона є його системоутворюючим чинником та активно впливає на стан економічної, політичної, оборонної та інших складових частин безпеки України. Від забезпечення транспортної безпеки суттєвим чином залежить національна безпека України, яка зростає в ході технічного прогресу. Безпека транспортного процесу сьогодні доповнюється вимогою забезпечення антитерористичної безпеки на транспорті.

Питанням забезпечення транспортної безпеки в Україні поки що приділяється недостатньо уваги. Зокрема, поки що не прийняті основні нормативні документи в цій сфері: стратегія та концепція транспортної безпеки, закон про транспортну безпеку. Заходи, які вживаються, зазвичай відрізняються невисокою ефективністю. Водночас забезпечення належного рівня транспортної безпеки є одним з основних завдань сучасної держави. Це підтверджується увагою, що приділяється сьогодні у розвинених країнах світу питанням безпеки, зокрема транспортної, а також зумовлено величезним значенням транспорту для будь-якої сучасної країни.

Аналіз останніх досліджень і публікацій. Проблеми, які стосуються транспортної безпеки, обліку на транспорті пріоритетних інтересів забезпечення національної безпеки, транспортної стратегії в морському, повітряному та наземному просторі, розглядалися у роботах М.К.Бандмана, А.В. Володіна, С.С. Гончаренко, К.Є. Каратаєвої, А.В. Ковтунова, В.А. Корзуна, А.Ф. Котляренко, П.В. Куренкова, В.А. Ламіна, Р.Г. Леонтьєва, А.Г. Мартинова, В.Ю. Малова, О.В. Соколової, В.А. Хмеля.

Виділення не вирішених раніше частин загальної проблеми. Хоча окремі питання, яким присвячено нашу роботу, розглянуті у працях вищезазначених та інших авторів, окремі аспекти цієї сфери потребують подальшого обговорення та вдосконалення.

Саме тому мета статті полягає у короткому розгляді факторів забезпечення транспортної безпеки, основних загроз на тран- спорті, основного спектру загроз транспортній безпеці, основних причин низького рівня транспортної безпеки в Україні. Доведено, що державне управління безпекою на транспорті потребуєвдосконалення, ізурахуваннямвищезазначеного зроблено відповідні висновки.

Виклад основного матеріалу. Надійне забезпечення транспортної безпеки стало сьогодні для багатьох країн світу, в тому числі і для України, одним із найактуальніших завдань, що зумовлено низкою факторів:

- безпрецедентною ескалацією тероризму і диверсій на транспорті, застосуванням із боку структур внутрішньодержавного і міжнародного тероризму нових, особливо небезпечних способів здійснення диверсійних актів (масовим використанням терористів-смертників і транспортних засобів як знарядь диверсії);

- активізацією національних і транснаціональних форм організованої злочинності, що спеціалізуються на незаконних зовнішньоекономічних операціях, контрабанді, нелегальній міграції та використовують транспортні артерії у своїх злочинних цілях;

- тісним переплетенням тероризму з міжнародним наркобізнесом - головним його фінансовим джерелом. Діяльність щодо підвищення рівня транспортної безпеки акумулює в собі не тільки протидію незаконному обігу наркотиків, а й припинення контрабанди зброї, боєприпасів, вибухових речовин, засобів здійснення диверсійних актів;

- безперервним зростанням інших форм неправомірного втручання у функціонування транспортного комплексу (блокування транспортнихшляхів, транспортнихзасобів, розкраданняіхуліганстванатранспортітощо), щопризводить до аварій і дестабілізації його роботи.

Зростання на транспорті числа аварій та інших надзвичайних ситуацій зумовлене не тільки порушенням правил експлуатації технічних систем, але і фізичним станом самих цих систем, високим ступенем зносу та їхньою технічною недосконалістю.

Щоб мати уявлення про ймовірні масштаби, загрози транспортній безпеці України, коротко розглянемо склад транспортного комплексу держави й основні загрози на транспорті.

Транспортний комплекс включає в себе транспортну інфраструктуру в повному обсязі: всі види транспортних засобів, включаючи підземний, а також трубопроводи, всі види доріг і шляхів, мости та тунелі, контактні лінії, всі види станцій і вокзалів, стоянки автотранспортних засобів, суден, всі види морських і річкових портів і портових засобів, гідротехнічні споруди, аеродроми, аеропорти, об'єкти системи зв'язку, навігації та управління рухом тран- 


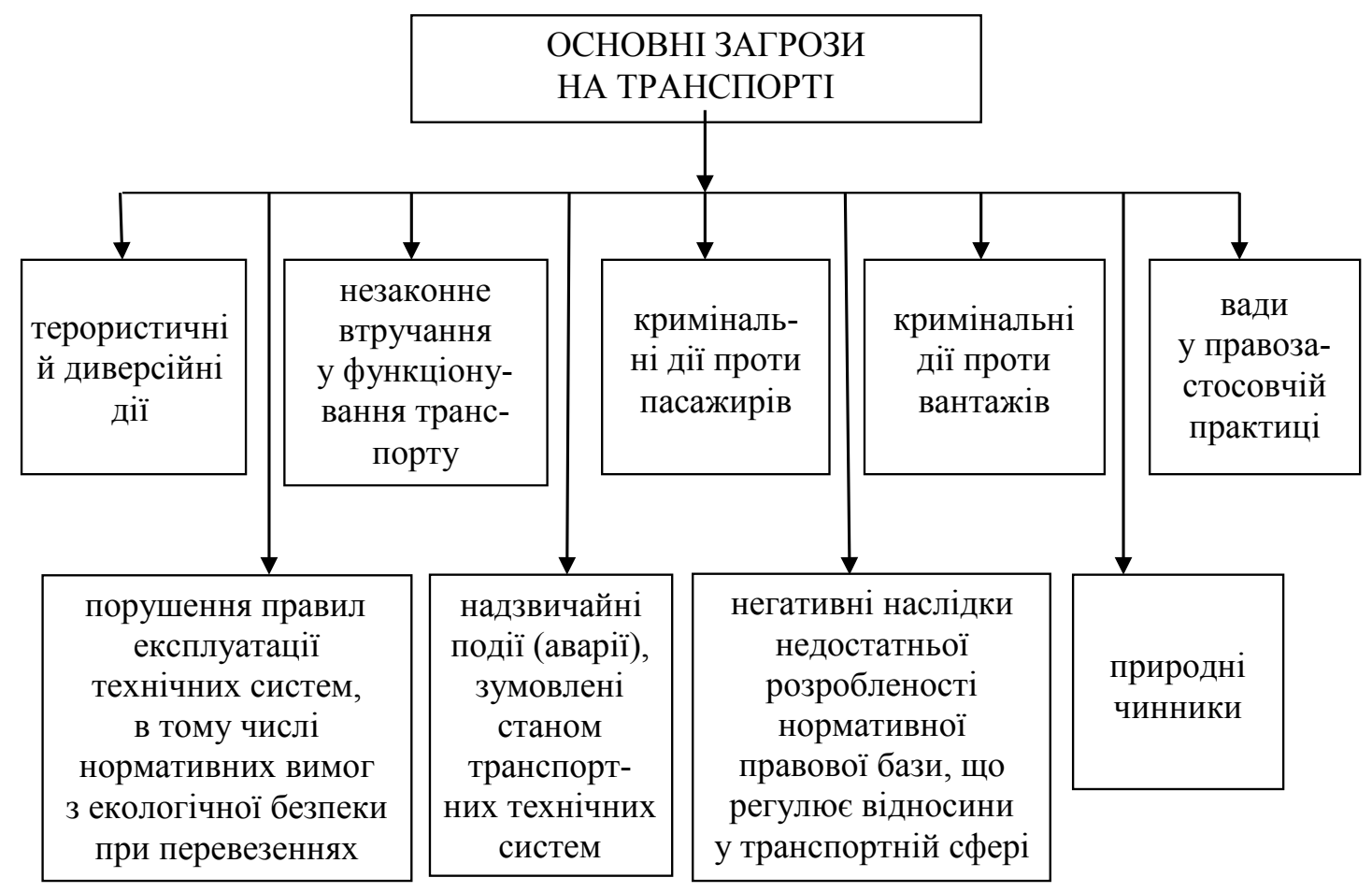

Рис. 1. Основні загрози на транспорті

спортних засобів, а також всі інші об'єкти, які забезпечують функціонування транспортного комплексу: будови, пристрої й устаткування.

Основні загрози на транспорті наведені на рис. 1.

Масштабний спектр різних причин природного, технічного і соціального характеру зумовлює наявність широкого діапазону внутрішніх і зовнішніх загроз, які ослаблюють транспортну безпеку країни.

Серйозні прорахунки, допущені на етапі проведення економічних реформ, послаблення системи державного регулювання i контролю, проникнення кримінальних структур до сфери управління бізнесом сприяють формуванню спектру загроз транспортній безпеці в економічній сфері. До них належать:

- недостатня ефективність системи державного регулювання відносин у сфері транспорту, наявність структурних диспропорцій, перешкод встановленню ринкових відносин;

- проблеми ресурсної, фінансової та технологічної залежності національного транспорту від інших країн, відставання України від провідних країн за рівнем інформатизації сфери транспорту;

- недостатнє фінансування заходів щодо забезпечення транспортної безпеки України;

- зниження рівня підготовки висококваліфікованих наукових та інженерно-технічних кадрів, нестача кваліфікованих фахівців у галузі забезпечення безпеки транспортута ін.
За діапазоном і рівнем можливих загроз транспортна інфраструктура належить до числа найбільш критичних з об'єктів, що зумовлено:

- зростанням транспортних перевезень небезпечних вантажів (нафти, хімічно небезпечних речовин, радіаційних матеріалів, відходів атомної промисловості до місця поховання);

- високим ступенем зношеності й аварійності об'єктів транспортного комплексу;

- зростанням інтенсивності руху транспорту в міру розвитку економіки країни, налагодження роботи міжнародних транспортних коридорів;

- зростанням дорожньо-транспортної аварійності, що є однією з найсерйозніших соціально-економічних проблем;

- фактом вдосконалення методів і способів протиправної діяльності злочинних формувань, насамперед терористичних організацій, щодо транспортного комплексу, посиленням небезпечної тенденції до об'єднання і координації їхньої діяльності на внутрішньодержавному і на міждержавному рівнях.

3 урахуванням багаторівневого визначення національної безпеки держави транспортну безпеку України необхідно розглядати не в аспекті захищеності транспорту (галузевий підхід), а з позиції геополітичного підходу забезпечення державних інтересів. Відповідно, транспортна безпека - це стан 
захищеності об'єктів транспортної інфраструктури, що дозволяє забезпечувати національну безпеку і національні інтереси в галузі транспортної діяльності та її стійкості, здатність запобігати нанесенню шкоди здоров'ю і життю людей, збитку майну та навколишньому середовищу, мінімізувати загальнонаціональний економічний збиток при транспортній діяльності [1, с. 17].

Транспортна безпека спрямована на досягнення:

- безпеки для життя, здоров'я пасажирів під час здійснення перевезення, а також посадки, висадки й очікування транспортного засобу, пристосованого для перевезення людей;

- безпеки перевезення вантажів і багажу, включаючи обмеження на переміщення небезпечних і негабаритних вантажів, спеціалізацію транспортних засобів для переміщення таких вантажів, розробку окремих маршрутів і встановлення обмежень за графіком використання магістралей загального призначення;

- безпеки експлуатації та функціонування транспортних об'єктів і засобів, регламентуючи вимоги до їх стану та проведення комплексу робіт із ремонту й обслуговування, унеможливлюючи доступ до небезпечних об'єктів (небезпечних через особливості свого функціонування для оточення, а також порушення нормальних умов функціонування яких може спричинити аварії або техногенні катастрофи);

- охорони громадського порядку на транспорті - сукупності установлених і взятих під охорону державою (в особі уповноважених державних органів, посадових осіб) правил поведінки у громадських місцях, на транспорті з метою реалізації прав громадян, іноземців, осіб без громадянства на безпечне переміщення, внаслідок якого задовольняються їхні відповідні інтереси, а також потреби державного розвитку;

- безпечного стану дорожніх умов шляхом розробки та впровадження організаційних, інженерно-технічних заходів, спрямованих на забезпечення збереження життя і майна учасників дорожнього руху, приведення у належний стан доріг, вулиць і залізничних переїздів, усунення причин виникнення місць концентрації ДТП, удосконалення організації руху транспорту тощо [2, с. 38].

Транспортна безпека насамперед проявляється у задоволенні транспортних потреб держави, її економіки, оборонного комплексу для стійкого та гармонійного розвитку суспільства, захисту його національних інтересів.

Системний характер поняття транспортної безпеки визначає необхідність комплексного, системного вирішення проблем у цій сфері.
Серед основних причин низького рівня транспортної безпеки в Україні можливо виділити:

- відсутність єдиної політики забезпечення транспортної безпеки в державі;

- недосконалість вітчизняного законодавства у сфері транспортної безпеки та відсутність основних нормативних документів для регулювання суспільних відносин у цій сфері: закону, концепції, стратегії та програми;

- неузгодженість і несистемний характер заходів і зусиль органів державної влади з підвищення рівня транспортної безпеки;

- низький рівень правосвідомості та дисципліни працівників і користувачів сфери транспорту;

- незадовільний технічний стан транспортних засобів, транспортних комунікацій та об'єктів, великий обсяг застарілих транспортних засобів і споруд в експлуатації на території України;

- вибухоподібне зростання кількості автотранспорту в країні на фоні відставання розвитку дорожньої інфраструктури;

- незадовільне фінансування заходів із підвищення рівня транспортної безпеки;

- низький рівень підготовки осіб, які впливають на стан транспортної безпеки, зокрема державних службовців у цій сфері, водіїв транспортних засобів та інших працівників транспортної сфери тощо [3, с. 89-90].

Аналіз системи й компетенції суб'єктів управління транспортним комплексом України засвідчує, що нинішня система державного управління безпекою на транспорті потребує вдосконалення. Відсутній єдиний орган управління транспортною безпекою держави, саме тому відсутня єдина загальна координація дій суб'єктів забезпечення транспортної безпеки України. Необхідне вдосконалення взаємодії всіх органів виконавчої влади та силових структур, які відповідають і беруть участь у забезпеченні транспортної безпеки. Згідно із завданнями та функціональними обов'язками правоохоронних органів, спецслужб і контролюючих служб повинні бути більш чітко визначені на законодавчому рівні їх роль, місце та відповідальність як учасників процесу забезпечення транспортної безпеки.

Таким чином, з урахуванням вищезазначеного можливо зробити такі основні висновки:

1. Транспортна безпека має велике значення для національної безпеки держави та всіх сторін життєдіяльності українського суспільства, особливо за сучасних умов глобалізації, економічної нестабільності держави та світової фінансової системи, глобальної економічної постпандемічної кризи. 
2. Від стану та якості безпечної роботи транспортної системи України залежать не тільки перспективи подальшого соціально-економічного розвитку, але й можливості держави ефективно виконувати такі важливі функції, як захист національного суверенітету та безпеки держави, забезпечення потреб громадян у перевезеннях, створення умов для розвитку соціально-економічних умов регіонів України.

3. Транспортна безпека $€$ не лише засобом регулювання транспортного процесу, а й передусім інструментом забезпечення інтересів держави, а її системний характер визначає необхідність комплексного, системного вирішення проблем, наявних у цій сфері.

4. Нинішня система державного управління безпекою на транспорті потребує вдосконалення, забезпечення їі належного рівня $€$ одним із основних завдань сучасної держави, що підтверджується увагою, яка приділяється сьогодні у розвинених країнах світу питанням транспортної безпеки.
Перспективами подальших розвідок у цьому напрямі вважаємо розгляд загроз транспортній безпеці України на різних видах транспорту із зазначенням ролі державного управління в цьому процесі.

\section{ЛITЕРАТУРА:}

1. Забезпечення безпеки на транспорті, дорожньому господарстві та об'єктах поштового зв'язку. URL: http://mtu.gov.ua/reforms/wp-content/uploads/ Zabezpechennya-bezpeki-na-transporti.pdf (дата звернення: 17.05.20).

2. Развадовський В.Й. Державне регулювання транспортної системи України (адміністративно-правові проблеми та шляхи їх розв'язання) : автореср. дис. ... докт. юрид. наук : 12.00.07. Харків : Національний ун-т внутр. справ, 2004.

3. Сапронов О. Основні напрями забезпечення транспортної безпеки України. Вісник Національної академії державного управління. 2009. Вип. 4. C. 87-95. URL: http://visnyk.academy.gov.ua/wp-content/ uploads/2013/11/2009-4-14.pdf (дата звернення 17.05.20). 